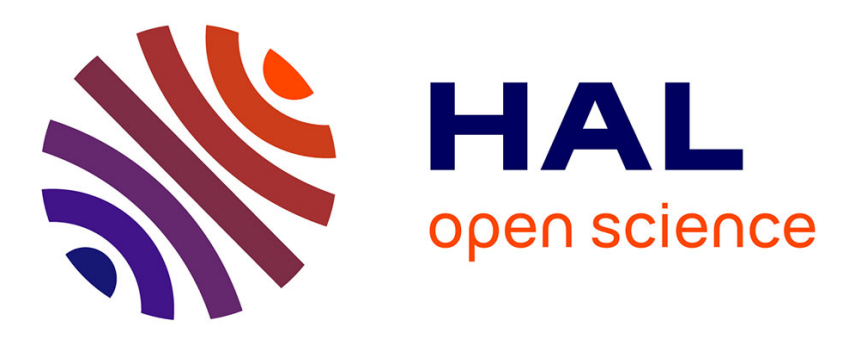

\title{
Determination of Granite Crack Resistance under Dynamic Loading
}

\author{
S. Novikov, V. Pushkov, A. Eremenko
}

\section{To cite this version:}

S. Novikov, V. Pushkov, A. Eremenko. Determination of Granite Crack Resistance under Dynamic Loading. Journal de Physique IV Proceedings, 1997, 07 (C3), pp.C3-1011-C3-1013. 10.1051/jp4:19973170 . jpa-00255462

\section{HAL Id: jpa-00255462 https://hal.science/jpa-00255462}

Submitted on 1 Jan 1997

HAL is a multi-disciplinary open access archive for the deposit and dissemination of scientific research documents, whether they are published or not. The documents may come from teaching and research institutions in France or abroad, or from public or private research centers.
L'archive ouverte pluridisciplinaire HAL, est destinée au dépôt et à la diffusion de documents scientifiques de niveau recherche, publiés ou non, émanant des établissements d'enseignement et de recherche français ou étrangers, des laboratoires publics ou privés. 


\title{
Determination of Granite Crack Resistance under Dynamic Loading
}

\author{
S.A. Novikov, V.A. Pushkov and A.S. Eremenko \\ Russian Federal Nuclear Center (VNIIEF), 607190 Sarov, Nizhni Novgorod region, Russia
}

\begin{abstract}
The paper describes the technique of $K_{l d}$ crack resistance determination (i.e. determination of critical coefficient of stresses intensity under plane strains) for rocks under dynamic loading. The technique is based on modified Kol'sky method of dynamic tests, where split-Hopkinson-bars are used. Tested compact specimen for wedging is placed between ends of two bars. Then it is subjected to dynamic loading. Value of crack resistance is determined using effort-ends shift diagram, obtained by experiment. Impact testing machine with rubber accelerator of striker is used for dynamic loading.

Granite specimens from Vyborgskoe deposit are tested. Values of $K_{l d}$ are obtained in the following interval of relative velocities of loading: $\bar{v}=(0.1-3.0) \cdot 10^{4} \mathrm{~s}^{-1}$.

Value of $\bar{v}$ is inversely proportional to time of effort increase up to critical value, when crack shifts.

Résumé. On propose la méthode pour estimer la résistance des rochers à la fissuration $\mathrm{K}_{\mathrm{Id}}$ (le coefficient critique de l'intensité des contraintes à la déformation plate) à cause du chargement dynamique. La méthode proposée est basée sur la méthode des essais dynamiques de Kolski modifjée, dans laquelle on applique les barres de Hopkinson coupées. La valeur de résistance à la fissuration est déterminée à partir du diagramme expérimental décrivant l'effort et le déplacement des abouts. Pour réaliser le chargement on utilise une sonnette avec l'accélérateur du percuteur en caoutchouc.

Les échantillons de granite du gisement Vyborgskoye ont été éprouvés. Les valeurs $K_{14}$ ont été obtenues dans la gamme des vitesses de mise en charge relatives $\bar{V}=(0.1-3.0) \cdot 10^{-4} \mathrm{~s}^{-1}$. La valeur $\bar{V}$ est inversement proportionnelle au temps d'augmentation de l'effort jusqu'à la valeur critique quand la fissure s'ébranle.
\end{abstract}

\section{Introduction.}

Under high-rate loading with characteristic time of loading $(1-5) \cdot 10^{-3} \mathrm{~s}$ and less some difficulties, caused by dynamic effects, are faced when employing standart schemes of testing for crack resistance. Effective techniques to determine dynamic crack resistance with the use of split-Hopkinson-bar (SHB) method and compact specimen for wedging were proposed in $[1,2]$. The authors have taken it as a basis. At such a scheme of specimen loading the wedging effort can be found using the formula:

$$
P(t)=E \cdot s \cdot \varepsilon_{t}(t)
$$

where $E, s$ - the elasticity modulus and the area of the bar's cross section; $\varepsilon_{q}(t)$-strain pulse arrived in the supporting bar.

The strain is calculated using approximated formula with no regards to the initial non-stationary phase, when strains are very small 


$$
\delta(t)=2 c \int_{0}^{t}\left[\varepsilon_{i}(t)-\varepsilon_{t}(t)\right] d t
$$

where $c$ - rate of elastic wave in the bars; $\varepsilon_{i}(t)$-the strain pulse, which falls on a specimen through the loading bar. Pulses $\varepsilon_{i}(t)$ and $\varepsilon_{t}(t)$ are recorded by tensoresistors on the bars. $P-\delta$ diagram is obtained by elimination of time $t$ from (1) and (2).

By the standart way [3] it is possible to determine the critical force $P_{c}$ from $P-\delta$ diagram, where this force corresponds to the destruction beginning, and which is used to calculate the value of dynamic crack resistance $K_{I d} . K_{I d}$ can be calculated using the formula

$$
K_{l d}=\frac{P_{c}}{S_{N}} \cdot \sqrt{l} \cdot Y
$$

where $S_{N}$ - data-sheet section of the specimen resistance; $l$ - length of the initial crack; $Y$ - calibrating function ( $K$ - calibration).

In this work the authors used a plane specimen for wedging with rectangular data-sheet section and a triangular cut-out for placement of a wedge-shaped end of the loading bar. It was modified from the specimen of WLCT (wedge-loaded compact tension) type [4].

The calibrating function $K$ of the specimen was determined by experiment with the use of the compliance method employing known Irwin-Keis relation [5]:

$$
K_{I}^{2}={\stackrel{P^{2} \cdot E_{0}}{2 B} \quad 1}_{2 B^{2}}^{1-\mu^{2}} \cdot \frac{d \chi}{d l} .
$$

Here $\chi=\delta / P$ is the specimen compliance determined using $P-\delta$ diagram with different lengths of cracks; $\mathrm{E}_{0}, \mu$ - the elasticity modulus and Poisson's ratio of the specimen material; $B$ - the specimen thickness.

Since the attempts to cause initial cracks in granite specimens were unsuccessful, calibration $K$ was determined using specimens from organic glass, which were similar in sizes and with known value of $K_{l d} . K_{I}$ values of granite and organic glass specimens without initial cracks differed by $10 \%$ or less.

It is convenient to assess velocity mode of loading using relative loading rate $\bar{v}$ determined as the reciprocal of time of loading increase from zero to $P_{c}$ :

$$
\bar{v}=\frac{\dot{K}_{I}}{K_{I d}}=\frac{K_{l d}}{t_{c}} \cdot \frac{1}{K_{I d}}=\frac{1}{t_{c}} .
$$

The limiting value $\bar{v}$ for conservation of the quasistatic conditions of loading is $(3-4) \cdot 10^{4-1}$ As this takes place, dynamic effects, caused by longitudinal and lateral inertia of the specimen and assessed using formulae from [4], are equal to $6 \%$ of $P_{c}$ or less. 


\section{Scheme of the experiment and obtained results.}

In the experiments for dynamic loading we used an impact testing machine with a rubber accelerator of the striker. The striker was accelerated up to $1-2 \mathrm{~m} / \mathrm{s}$ and striked against special damper, fastened on the loading bar. The damper forms the loading pulse. The bars were manufactured from 30KhGSA steel with the following sizes: $\varnothing 16 \times 900 \mathrm{~mm}$ (the loading bar) and $\varnothing 16 \times 900 \mathrm{~mm}$ (the supporting bar). We manufactured plane specimens with height $(2 \mathrm{H})$, width $(\mathrm{W})$, thickness (B) of two typical sizes $(2 H \times W \times B): 20 \times 24 \times 14 \mathrm{~mm}$ and $14 \times 17 \times 8 \mathrm{~mm}$. Specimens with less sizes were manufactured from fragments of specimens, cracked during the experiments. The specimens had a triangular cut-out with the depth of $10 \mathrm{~mm}$. Value of the cut-out, where the specimen was connected with the wedge-shaped end of the loading bar, was equal to $30^{\circ} . S_{N}=B \cdot W$ was assumed as data-sheet section of the resistance. Granite specimens from Vyborgskoe deposit were prepared for testing. Preliminarily we studied structure, determined elastic constants $E_{0}, \mu$ and density $\rho$ of the material. The were: $E_{0}=7 \cdot 10^{4} \mathrm{MPa}, \mu=0.25$, $\rho=2.65 \cdot 10^{3} \mathrm{~kg} / \mathrm{m}^{3}$. The grain value, measured on the destruction surface, was $1-1.5 \mathrm{~mm}$.

To decrease friction influence, we lubricated contacting surfaces of the specimen and the wedgeshaped end of the bar with specially selected lubricant. According to our assessments, the use of the lubricant allowed to reach the friction coefficient of 0.05 or less due to low contacting pressures (several megapascals) and small displacements $\delta(0.03-0.6 \mathrm{~mm})$. All experiments were carried out at the normal temperature. The loading rates interval was $10^{3}<\bar{v}<3 \cdot 10^{4} s^{-1}$. Granite destruction had brittle character. This destruction took place along glass-like intergrain sublayers. $K_{I d}$ values of granite, obtained in the experiments, are tabulated in the table.

Table

\begin{tabular}{|c|c|c|c|c|c|}
\hline $\begin{array}{c}2 H \times W \times B, \\
\mathrm{~mm}\end{array}$ & $v, 10^{4}, s^{-1}$ & $\begin{array}{c}K_{I d}, \\
\mathrm{MPa} \cdot \mathrm{m}^{1 / 2}\end{array}$ & $\begin{array}{c}2 H \times W \times B, \\
\mathrm{~mm}\end{array}$ & $\bar{v}, 10^{4}, s^{-1}$ & $\begin{array}{c}K_{I d}, \\
\mathrm{MPa} \cdot \mathrm{m}^{1 / 2}\end{array}$ \\
\hline & 0,12 & 1,18 & & 0,10 & 1,16 \\
& 0,10 & 1,15 & & 0,11 & 1,08 \\
& 1,30 & 1,05 & $14 \times 17 \times 8$ & 0,80 & 1,20 \\
& 1,40 & 1,16 & & 0,95 & 1,10 \\
& 1,50 & 1,18 & & 1,20 & 1,15 \\
& 2,60 & 1,28 & & 2,50 & 1,20 \\
& 1,80 & 1,10 & & 3,10 & 1,19 \\
\hline
\end{tabular}

$K_{I d}$ has no dependence on $\bar{v}$, and the average value of $K_{I d}$ is $1,16 \pm 0,16 \mathrm{MPa} \cdot \mathrm{m}^{1 / 2}$ in the studied range of loading rates. The granite destruction energy, determined using Griffiths criterion for the case of plane deformation, is $18 \pm 0,5 \mathrm{~J} / \mathrm{m}^{2}$.

\section{References}

1. A.P.Bolshakov, A.S.Eremenko, V.A.Lupsha et al., Physics-chemical mechanics of materials 1 (1981) 79-82.

2. A.Andrzejewski, J.Klepaczko, G.Pluvinage, J.Mech.Appl. 5 (1981) 345-366.

3. U.F.Brown, D.E.Srowly., Testing of high-strength metal materials for viscosity of destruction under plane deformation (Mir, Moscow, 1972)

4. J.R.Klepaczko., Theoretical basis of engineering calculations 104 (1982) 33-40.

5. K.B.Baknell., Impact-proof plastics (Chemistry, Leningrad, 1981). 